TECHNICAL PROGRESS REPORT

for the Fourth Quarter of FY 1995

(July 1, 1995 - September 30, 1995)

\title{
UPGRADED COAL INTEREST GROUP
}

by

William Weber

Electric Power Research Institute

516 Franklin Building

Chattanooga, TN 37411

and

Howard E. Lebowitz

Fossil Fuel Sciences

644 Emerson Street, Suite 12

Palo Alto, CA 94301

\section{Project Manager:}

Richard Read

U.S. Department of Energy

Pittsburgh Energy Technology Center

P.O. Box 10940

Pittsburgh, Pennsylvania 15236

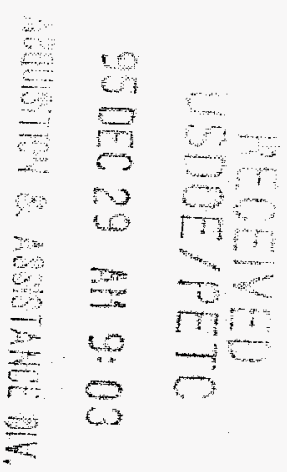




\begin{abstract}
The group met on September 7 and 8 inPittsburgh. Technical presentations were made on the following subjects:

- Technical Consultant's Report (Howard Lebowitz)

- Trace elements in coal (Bob Finkelman-USGS, Dave Akers-CQ Inc. and Gerald Luttrell-VPI)

- Sulfur removal by oxidation (Barbara Arnold-CQ Inc.)

- Fines transportation cost model prototype (Dave Kehoe-CQ Inc)

- Carbon Removal from fly ash seminar- (Michigan Technical University and Separation Technologies)

- Stamet Feeder (Stamet,Inc.-Anne Stephenson)

- Presentation and demonstration on the Exportech Mag-Mill (Robin Oder)
\end{abstract}

Copies of the technical manager's presentation and the presentations on the fines transportation model and Mag-Mill are included.

\title{
PROJECT OBJECTIVES
}

The objectives of the Upgraded Coal Interest Group (UCIG) are as follows:

- Review and update the status of various coal upgrading technologies and developments and critically assess the results.

- Perform engineering screening analyses on various coal upgrading approaches.

- Perform commercialization analyses that will promote the availability and use of upgraded coal products by quantifying the benefits of using them. Identify market opportunities for introduction of upgraded coals.

- Perform critical analyses on a variety of coals and technologies in areas important to users but not readily available. Perform critical experiments which will show the differences between technologies.

\section{DISCLAIMER}

\footnotetext{
This report was prepared as an account of work sponsored by an agency of the United States Government. Neither the United States Government nor any agency thereof, nor any of their employees, makes any warranty, express or implied, or assumes any legal liability or responsibility for the accuracy, completeness, or usefulness of any information, apparatus, product, or process disclosed, or represents that its use would not infringe privately owned rights. Reference herein to any specific commercial product, process, or service by trade name, trademark, manufacturer, or otherwise does not necessarily constitute or imply its endorsement, recommendation, or favoring by the United States Government or any agency thereof. The views and opinions of authors expressed herein do not necessarily state or reflect those of the United States Government or any agency thereof.
} 
Technical Manager's Report

Howard E. Lebowitz

Fossil Fuel Sciences 


\title{
Potential Renewal SECTION 29 Tax Credits
}

\section{CONGRESSIONAL BUDGET DELIBERATIONS}

\author{
CONFERENCE REPORT ON SETTING BUDGET FOR FISCAL 1996-2002 \\ FILED JUNE 26, 1995
}

The House resolution anticipates that the Committee on Ways and Means will explore restoration or continuation of certain tax and trade provisions which have expired or will soon expire as well as certain other tax measures. It is expected that the Committee on Ways and Mean-in seeking to offset the cost of these measures-will look to changes reducing inappropriate corporate tax benefits, other appropriate revenue offsets, and spending reductions within the Committees' jurisdiction.

Senate amendment:

The Senate amendment assumes no net change in revenues from the current law level over the period 1996-2000 or over the period 1996-2002. The Finance Committee is given no revenue reconciliation instructions.

The Senate amendment assumes that the Finance Committee will act to extend expiring provisions so long as the net revenue reductions are no greater than $\$ 3.7$ billion over five years and $\$ 3.8$ billion over seven years. The Finance Committee may decide to raise some revenues by extending expiring taxes, and reduce some revenues by extending other expiring provisions. Possible extensions of current taxes that raise revenue include: corporate tax dedicated to Superfund, FETA 0.2 percentage point surtax, luxury tax on passenger vehicles, 1.25 cents/gallon railroad diesel fuel tax, 2.5 cents/gallon motorboat gasoline tax, and the 20.1 cents/gallon motor-boat diesel fuel tax. Possible extensions of expiring provisions that lose revenue include: the commercial aviation exemption from the fuel tax, deduction for contributions to private foundations, targeted jobs tax credit, exclusion for employer-provided education assistance, orphan drug tax credit, research and experimentation tax credit and allocation rules, generalized system of preferences, deny deduction for some noncomplying health plans (ERISA waiver), and the nonconventional fuels tax credit. 


\section{Potential Renewal \\ SECTION 29 Tax Credits}

\section{Two Bills Introduced}

House Resolution 379

A BILL To amend the Internal Revenue Code of 1986 to define tar sands for purposes of the credit for producing fuels from nonconventional sources and to repeal the minimum tax preference for intangible drilling costs.

DATE OF INTRODUCTION: JANUARY 9, 1995

SPONSORS(S): Mr. THOMAS

STATUS: Referred to the Committee on Ways and Means

Information for Public Affairs, Inc. estimates the odds of passage as follows:

HOUSE COMMITTEE ON WAYS AND MEANS $\quad 6 \%$

SENATE COMMITTEE

HOUSE $\quad 5 \%$

SENATE $\quad 3 \%$ 


\section{Potential Renewal SECTION 29 Tax Credits}

\section{House Resolution 2146}

A BILL To amend the Internal Revenue Code of 1986 to extend the nonconventional fuel tax credit.

INTRODUCED: JULY 31, 1995

SPONSOR(S):

Mrs. JOHNSON of Connecticut

STATUS: Referred to the Committee on Ways and Means

\section{TEXT:}

Be it enacted by the Senate and House of Representatives of the United *States of America in Congress assembled, SECTION 1. TEMPORARY EXTENSION OF NONCONVENTIONAL FUEL CREDIT.

(a) IN GENERAL.-Section 29(g)(1) of the Internal Revenue Code of 1986 (relating to the nonconventional fuel credit) is amended-

(1) by striking "1997, pursuant to a binding written contract in effect before January 1, 1996" and inserting "2001" in subparagraph (A),

(2) by striking "if such facility is originally placed in service after December 31, 1992" in subparagraph (B), and

(3) by striking "2008" and inserting "2012" in subparagraph (B).

(b) EFFECTIVE DATE.-The amendments made by this section shall take effect upon enactment.

Section. 2. PERMISSION FOR PRODUCERS TO USE QUALIFIED FUEL TO GENERATE ELECTRICITY.

(a) IN GENERAL.-Section 29(d) of such Code is amended by adding at the end thereof the following new paragraph:

"(9) CERTAIN ELECTRICITY SALES.-A qualified fuel shall be treated as sold by the taxpayer to an unrelated person if the taxpayer uses the fuel to generate electricity which it sells to an unrelated person."

(b) EFFECTIVE DATE.-The amendment made by this section shall apply to qualified fuels used to generate electricity after enactment.

Probability not yet evaluated by Information for Public Affairs, Inc. 


\section{Potential Renewal of SECTION 29 Tax Credits The Administration}

Written Statement of Leslie B. Samuels Assistant Secretary (Tax Policy) Department of the Treasury Before the House Committee on Ways and Means (June 28)

\section{Modifications to Tax Credit for Producing Fuels from Nonconventional Source}

(a). Allow the Credit to Be Claimed Against the Alternative Minimum Tax

Administration Position. Oppose. There is no reason that energy credits should be subject to substantially more favorable treatment than other tax credits, which generally are not allowed against the alternative minimum tax ("AMT"). The purpose of the AMT, to assure that taxpayers with economic income are subject to tax, will be weakened if credits may be fully utilized against it.

\section{(b). Unrelated Party Sale Requirement}

Administration Position. Oppose. Under either proposal, a taxpayer would have the incentive to erect an electric plant, sell electricity produced from self-generated gas on the national grid, receive the credit, and buy back the electricity from the national grid rather than using its own self-generated electricity. Use of self-generated electricity is already a common practice for many industries without the credit; therefore, this proposal would expand use of the section 29 credit beyond what was originally intended. Moreover, absent an arm's-length transaction, the amount of section 29 gas "constructively" or"deemed" sold would not be verifiable. Finally, the number of potential taxpayers who could claim the section 29 credit under the proposal (and hence the amount of the associated revenue loss) is far greater than originally estimated by Treasury in 1993 , when the proposal was previously considered.

\section{(c). Underground Coal Gasification}

Administration Position. Oppose. The proposal would allow certain modules newly drilled within a coal production area to qualify for the section 29 credit. If there is an existing above ground gas transportation system to bring the gas generated from in-situ processing to an existing above ground facility for further processing. This could expand the use of the credit virtually indefinitely for a given coal seam and would, therefore, disadvantage other facilities that would have to comply with the placed-in-service expiration date.

\section{(d). Definition of Tar Sands}

Administration Position. Oppose. The placed-in-service date for wells from tar sands to qualify for the section 29 credit expired at the end of 1992. The source of the definition of tar sand presently in use by the IRS is a ruling by the Federal Energy Administration. The Tax Court has determined that this definition is the proper definition for purposes of section 29 the Code. In addition, there is no tax policy justification for creating a windfall by recharacterizing a significant number of deposits as eligible for the credit, when the oil or gas has already been economically produced. Moreover, the Administration would anticipate substantial difficulty implementing any standard that requires measurement of a gas-free viscosity at original reservoir temperature. 


\section{The Press}

In particular, Clinton ought to embrace the goal of aggressive deficit-reduction while defending - with his veto pen - spending priorities very different from those evident in the GOP proposals. The administration and its allies should come up with a plan that, unlike the Republican budget resolutions, does not:

Focus spending cuts on the young and the poor. House and Senate proposals would hack at the earned income tax credit and funds for prenatal care, child nutrition and Head Start. Aside from their meanness to vulnerable people, such cuts would harm the nation's future (a point Congress unwittingly acknowledges with proposals to increase prison funding).

Spare corporate welfare from substantial cuts. House Budget Committee Chairman John Kasich offered a token pledge to cut $\$ 25$ billion in unspecified corporate subsidies, but even this was blocked by other senior Republicans. Neither the House nor Senate resolutions would eliminate such special-interest boondoggles as the $\$ 4.1$ billion percentage-depletion allowance for oil, gas and mining companies, or the $\$ 5.7$ billion tax credit for producers of fuel from "nonconventional sources."

\section{Overall Conclusion}

Previous extensions have been "pushed" by the senate. It appears from all of the "smoke" that the Congress is giving serious consideration to extending the credits in some manner. 


\section{COMMERCIALIZATION NEWS}

\section{KENNECOTT PROJECT}

KENNECOTT ENERGY DECIDED TO ABANDON ITS PLANS FOR A PROCESSING PLANT NEAR CORDERO MINE IN WYOMING. REPORTEDLY THEY COULD NOT MOVE FAST ENOUGH TO MEET THE TIMING FOR THE SECTION 29 TAX CREDITS (ON STREAM BY THE END OF 1996). THE PROJECT DID NOT HAVE THE ECONOMICS TO GO FORWARD WITHOUT THE CREDITS.

THEY MIGHT RECONSIDER IN THE FUTURE.

\section{SOUTHERN CO. PROJECT}

COAL OUTLOOK (MAY 22, 1995 AND JULY 17, 1995) REPORTED THAT SOUTHERN CO. IS WORKING WITH CARBONTEC ENERGY AND THE OWNERS OF COAL MINES ABOUT INVESTING IN A FACILITY TO BE LOCATED IN WYOMING.

- PILOT SCALE COMBUSTION TESTS WERE RUN EARLIER IN THE YEAR AT SOUTHERN RESEARCH INSTITUTE ON THREE PRODUCTS: DRIED BELLE AYR COAL, REGULAR BELLE AYR COAL AND COAL FROM ARCH MINERAL'S LONE MOUNTAIN FACILITY (REPRESENTATIVE OF HIGH-BTU, LOW- SULFUR CENTRAL APPALACHIAN COAL).

- SOUTHERN IS INTERESTED IN GETTING THE LOW-NOX PERFORMANCE OF A PRB COAL IN A PRODUCT THAT LOOKS AND ACTS LIKE BITUMINOUS COAL.

- SOUTHERN LOOKING AT 1 MLLION TONS/YEAR FOR THEMSELVES AND A SIMILAR AMOUNT TO SELL.

- WOULD BE A SCALE UP FROM 20 TONS/WEEK PILOT PLANT

- Progressed to talking to CarbonTeC aNd COAl OWNERS. PRINCIPAL CONCERN REPORTED TO BE A LONG TERM PRICING ARRANGEMENT WITH THE COAL SUPPLIER.

\section{K - FUEL}

THERMO ECOTEK CORP. OF WALTHAM, MASSACHUSETTS HAS ANNOUNCED THAT IT WILL INVEST $\$ 42$ MILLION TO BUILD A K-FUEL PLANT IN WYOMING. THE PLANT WILL BE OWNED BY THERMO ECOTEK (95\%) AND KFX. A PRODUCT SALES AGREEMENT HAS BEEN SIGNED WITH OHIO VALLEY ELECTRIC. ADDITIONAL UTILITY CUSTOMERS ARE BEING SOUGHT. KFX WAS UNABLE TO PROVIDE A DETAILED INFORMATION PACKAGE FOR THIS MEETING, BUT WILL PROVIDE A PACKAGE FOR THE MINUTES. 


\section{CUSTOM COALS}

COAL OUTLOOK (JULY 3, 1995) REPORTED THAT CUSTOM COALS HAS RECEIVED APPROVAL FOR FINAL DOE FUNDING FOR THE LAUREL PROJECT SOMERSET COUNTY, PA. THE FINAL $\$ 12$ MILLION OF DOE FUNDS WILL BE USED FOR START UP OF THE PLANT AND TEST BURNS AT DUQUESNE LIGHT, CENTERIOR ENERGY, AND RICHMOND (IND.) POWER \& LIGHT.

- WORK HAD STOPPED FOR SEVERAL MONTHS EARLIER IN THE YEAR

- ALL EQUIPMENT NOW ON THE SITE AND COMPLETION OF CONSTRUCTION IS PROCEEDING.

- BASIC PROCESS (CARE-FREE COAL) IS DESIGNED TO REMOVE UP TO $90 \%$ OF THE PYRITIC COAL. DUQUESNE LIGHT WILL TEST CARE-FREE COAL MADE FROM SEWICKLEY SEAM COAL.

- CARE-FREE COAL BLENDED WITH LIMESTONE IS THE SECOND PRODUCT, KNOWN AS "SELFSCRUBBING COAL" WILL BE USED FOR COALS WITH HIGHER ORGANIC SULFUR.

- RICHMOND (IND.) POWER \& LIGHT WILL TEST A SELF-SCRUBBING COAL MADE USING AN ILLINOIS NO. 5 SEAM COAL, AND CENTERIOR ENERGY WILL TEST A PRODUCT MADE USING AN OHIO 


\section{HAZARDOUS AIR PRECURSORS}

EPA DRAFT RISK ASSESSMENT INDICATES CHROMIUM AND ARSENIC ARE THE MOST DANGEROUS INHALATION CARCINOGENS.

FURTHER STUDY IS NEEDED OF THESE SUBSTANCES AS WELL AS BERYLLIUM, CADMIUM, DIOXINS/FURANS, FORMALDEHYDE, HYDROGEN CHLORIDE, LEAD, MANGANESE, MERCURY, NICKEL, N-NITROSODIMETHYLAMINE, AND RADIO NUCLIDES.

THE STATE AND TERRITORIAL AIR POLlution PROGRAM ADMINISTRATORS AND ASSOCIATION OF LOCAL AIR POLLUTION CONTROL OFFICERS (STAPPA/ALAPCO) SAY THE DATA ARE INCOMPLETE.

STAPPA/ALAPCO HAVE VOICED CONCERN ABOUT THE LACK OF STUDY OF HUMAN-HEALTH EFFECTS FROM INGESTION OF POLLUTANTS EMTTED BY POWER PLANTS AND SKIN EXPOSURE TO THE SUBSTANCES. THE GROUPS ALSO CRITICIZE THE STUDY'S FAILURE TO ADDRESS EXPOSURE OVER LONG DISTANCES AND THROUGH MULTIPLE PATHWAYS.

\section{GREAT LAKES INITIATIVE}

THE ENVIRONMENTAL PROTECTION AGENCY PROPOSED A SWEEPING WATER QUALITY INITIATIVE FOR THE GREAT

LAKES EARLIER IN THE YEAR TO MEET A COURT-IMPOSED DEADLINE IN A LAWSUIT BROUGHT BY THE NATIONAL WILDLIFE FEDERATION.

THE PLAN SETS WATER QUALITY CRITERIA LEVELS FOR 22 "BIOACCUMULATIVE CHEMICALS OF CONCERN," INCLUDING MERCURY, DIOXIN AND PCBS. THE DOCUMENT CALLS FOR STATE AND LOCAL REGULATORS TO PROPOSE STANDARDS, SUBJECT TO EPA APPROVAL, BASED ON THE EPA CRITERIA WITHIN TWO YEARS.

THE INITIATIVE PROVIDES WIDE FLEXIBILITY TO STATE AND LOCAL REGULATORS TO DEVELOP STANDARDS AIMED AT REDUCING POLLUTANTS TO THE CRITERIA LEVEL.

THE CRITERIA LEVEL FOR MERCURY (1.3 PPT) COULD POSE SIGNIFICANT IMPLICATIONS FOR MERCURY EMITTERS, SUCH AS COAL-FIRED GENERATORS AND MUNICIPAL WASTE COMBUSTORS.

EPA'S STRATEGY CALLS FOR ALLOWING THE EIGHT GREAT LAKES STATES TO DETERMINE SOURCES OF MERCURY

EMISSIONS IN THE LAKES AND THE BEST WAY TO CURB THEM.

THE PROBLEM IS DETERMINING IF THE POLLUTANT IS CARRIED BY AIR OR BY WATER. IN THE CASE OF MERCURY

EMISSIONS, IT IS USUALLY A COMBINATION WITH THE PRIMARY SOURCE DIFFERING BY LOCATION. 
MOST OF THE AIR EMITTERS OF MERCURY ARE IN THE EIGHT STATES SURROUNDING THE GREAT LAKES (ILLINOIS,

INDIANA, Michigan, MinNESOTA, NEW YoRK, OHIO, PENNSYLVANIA AND WisCONSIN).

IN FORMING THE GREAT LAKES STUDY, EPA USED INFORMATION COLLECTED FOR A NATIONAL MERCURY STUDY, WHICH IS IN THE DRAFT STAGE.

RANKING AS THE HIGHEST EMITTERS OF MERCURY IN THE NATIONAL STUDY ARE: MEDICAL AND MUNICIPAL

WASTE INCINERATORS; COAL-FIRED ELECTRIC UTILITIES; CHLOR-ALKALI PLANTS USING THE MERCURY CELL PROCESS;

PRIMARY COPPER AND PRIMARY LEAD SMELTERS; CEMENT MANUFACTURERS; AND SECONDARY MERCURY PRODUCTION.

Might ULTIMATELY BE WATERED dOWN IN THE REAUTHOIZATION OF THE ClEAN WATER ACT. 


\section{WHAT ARE UTILITIES GOING TO DO FOR CAA COMPLIANCE?}

- RECENT EPRI/ICAC (INSTITUTE OF ClEAN AIR COMPANIES) PAPER PREDICTED MUCH MORE COAL SWITCHING THAN SCRUBBING WITH A 12 TO 20 GW BASE CASE FOR PHASE 2, PROBABLY CLOSER TO 12 GW (RECENT EPRI SPONSORED SCRUBBER CONFERENCE)

- UTLITIES WILL DELAY SCRUBBER COMMTTMENTS AS LONG AS POSSIBLE.

- MANY utilities haVe lots Of Phase 1 CRedits.

- MANY UTILITIES WILL NOT WANT THE ADDED DEBT ASSOCIATED WITH SCRUBBERS GOING INTO DEREGULATION.

- The Air ToXic Regulations (If ANY) DUE FROM EPA ON NoV. 15, PRESENT AN UNCERTAINTY.

- $\quad$ Fuel is USUALLy a UTIITY'S LARGEST EXPENSE (RANGES FROM 10 TO 40\% OF TOTAL OPERATING EXPENSES FOR UCIG MEMBERS)

- FUEL FLEXIBILITY IS PROBABLY THE MOST IMPORTANT FACTOR THAT A UTILITY CAN CONTROL FOR CAA COMPLIANCE, AND COMPETITIVENESS.

COAL OUTLOOK (AUGUST 14, 1995) REPORTED THAT THE RECENT CINERGY CAA PLAN FILED AS PART OF THEIR LONG RANGE PLAN, CALLS FOR SWITCHING TO 50\% PRB COAL AT GIBSON UNIT 3 IN 1997. GIBSON 1, 2 AND 3 WOULD SWITCH TO 100\% PRB IN 2003. 


\section{CHEMICAL COAL CLEANING}

\section{COST BASED ON THE BECHTEL ENGINEERING STUDY WITH VARIATIONS BY LEBOWITZ}

BASIS:

$\$ 165,800,000$ TOTAL CAPITAL

- 100 TONS PER HOUR CAPACITY X 85\% OPERATING FACTOR $=85$ TONS PER HOUR AVERAGE

- $12 \%$ COST OF MONEY - 10 YEAR RECOVERY SIMPLE DCF RETURN

- $60 \%$ CONTINGENCY - $40 \%$ PROCESS AND $20 \%$ PROJECT

- MaINTEnance@ $9 \%$ of Plant CAPITAl Cost

- $3 \%$ INFLATION

\section{VARIATIONS:}

- $15 \%$ CONTINGENCY

- $\quad 10 \%$ COST OF MONEY

- 25 YEAR RECOVERY

\begin{tabular}{|l|l|l|l|}
\hline CAPITAL COST & FINANCING & PROJECT TERM & $\begin{array}{l}\text { FIRST YEAR COST, } \\
\$ \text { MM BTU }\end{array}$ \\
\hline $60 \%$ CONTINGENCIES & $12 \%$ MONEY & 10 & $\$ 2.42$ \\
\hline $60 \%$ CONTINGENCIES & $10 \%$ MONEY & 10 & $\$ 2.28$ \\
\hline $15 \%$ CONTINGENCIES & $12 \%$ MONEY & 10 & $\$ 1.45$ \\
\hline $15 \%$ CONTINGENCIES & $10 \%$ MONEY & 10 & $\$ 1.38$ \\
\hline $15 \%$ CONTINGENCIES & $12 \%$ MONEY & 25 & $\$ 1.20$ \\
\hline $15 \%$ CONTINGENCIES & $10 \%$ MONEY & 25 & $\$ 1.12$ \\
\hline
\end{tabular}




\section{CHEMICAL COAL CLEANING \\ ORGANIC SULFUR REMOVAL \\ TECHNICAL PROGRESS \\ IOWA STATE UNIVERSITY PROJECT}

- $\quad$ PENELEC FEED COAL

SULFUR IN THE FEED COAL $\quad 1.87 \%$

SULFUR IN THE PRODUCT $\quad 0.82 \%$

ON COMBUSTION VERY LITTLE SULFUR IS NOTED IN THE FLUE GAS. THIS EFFECT DOESN'T

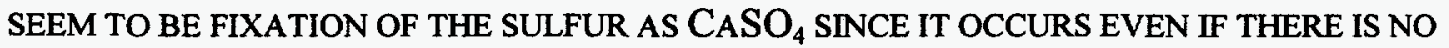
LIME ADDITION.

- $\quad$ PITTSBURGH 8 COAL - CAPTO ANALYSIS

\begin{tabular}{|l|l|l|}
\hline & FEED COAL & TREATED COAL \\
\hline PYRITE & 0.69 & 0.16 \\
\hline SULFATE & 0.12 & 0.00 \\
\hline ELEMENTAL & 0.00 & 0.00 \\
\hline AROMATIC & 1.95 & 0.21 \\
\hline NON-AROMATIC & 0.47 & 0.10 \\
\hline UNIDENTIFIED & 0.00 & 0.49 \\
\hline TOTAL & 3.24 & 0.95 \\
\hline
\end{tabular}




\title{
Q CQInc.
}

\section{DEVELOPMENT OF A FINE COAL TRANSPORTATION MODEL}

\author{
$C Q$ Inc. \\ Homer City, Pennsylvania \\ (412) 479-3503 \\ Glenn Shirey \\ Dave Kehoe
}

Upgraded Coal Interest Group

September Meeting

September 7-8, 1995

Pittsburgh, PA 


\section{FINE-COAL TRANSPORTATION MODEL}

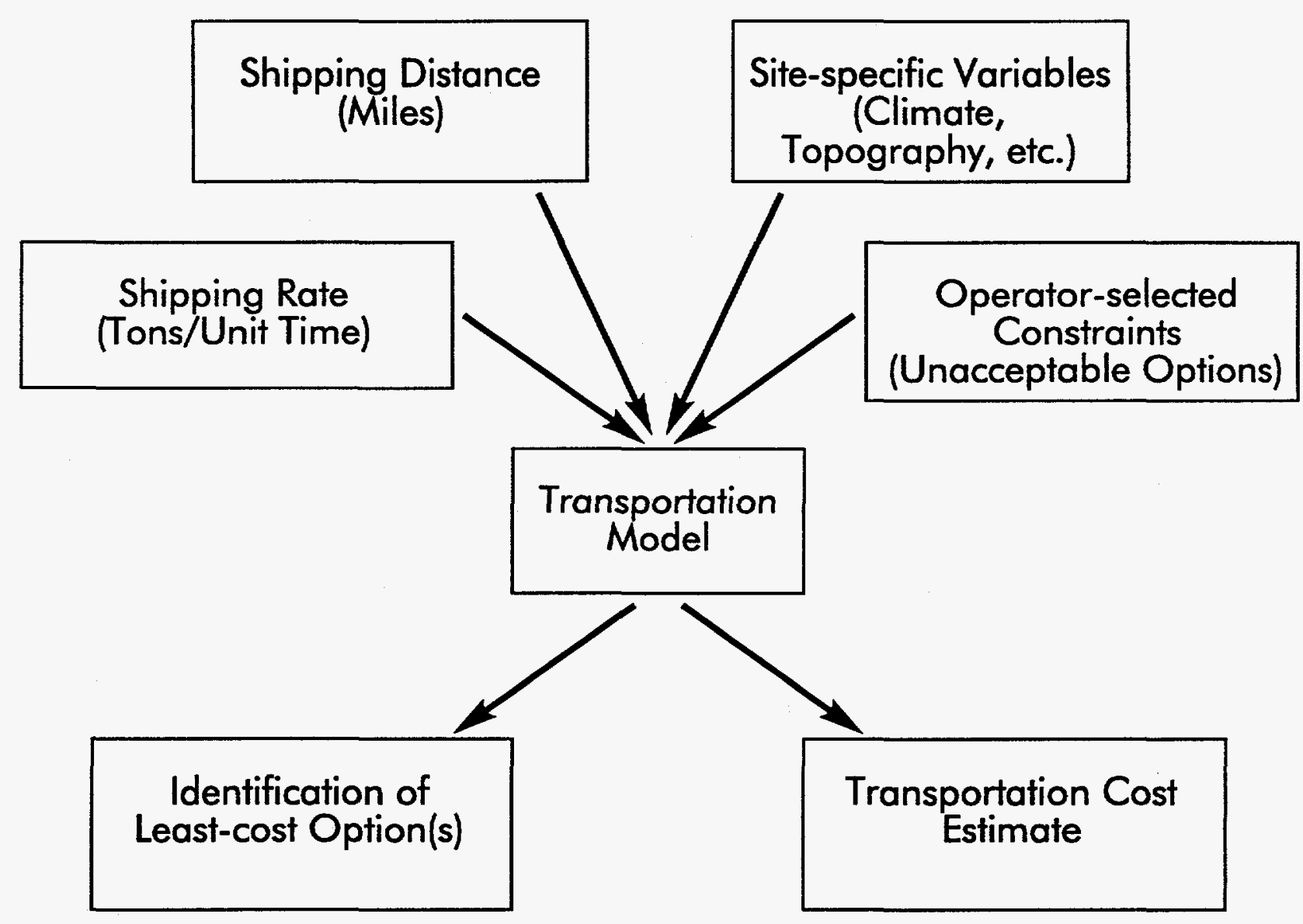




\section{FINE COAL TRANSPORTATION MODEL}

TRANSPORT \& PREPARATION

- Dewatered Solids Transport

--Truck

--Rail

--Barge

- Slurry Transport

--Tanker Car (truck, rail, barge)

--Pipeline

- Preparation at Source

--Mechanical Dewatering

--CWS Preparation

- Preparation at Power Plant

--Mechanical Dewatering

--Reslurrying 


\section{FINE COAL TRANSPORTATION MODEL}

DATA SOURCES

- Truck, Rail, Barge

--ElA Coal Transportation Rate Data Base

--Interstate Commerce Commission

--Inland Water Guide

--Barge \& Rail Carriers

- Slurry Pipeline

--Williams Technologies, Inc. (Black Mesa)

--Pipeline Systems Inc. (Walnut Creek, CA)

--Univ. of Missouri CPRC

--DOE-PETC

--Battelle Laboratories

--Coal \& Slurry Technology Conferences

--JWR/SCS Coal Water Slurry Study (1993)

- Dewatering/Slurrying Costs

--EER/MATS Study (Paradise \& Seward Stations)

--EPRI Coal Cleaning Cost Model 


\section{FINE COAL TRANSPORTATION MODEL}

\section{CONVENTIONAL COAL TRANSPORTATION COSTS}

Appalachia

(1990\$)

\begin{tabular}{|l|r|r|r||}
\hline & $\begin{array}{r}\text { Avg Haul } \\
\text { (miles) }\end{array}$ & \$/Ton & \$/Ton-mile \\
\hline Truck & 29 & 5.02 & 0.119 \\
\hline Rail & 334 & 11.71 & 0.032 \\
\hline Barge & 202 & 2.38 & 0.012 \\
\hline
\end{tabular}

Source: EIA Trends in Contract Coal Transportation, 1979-87 (Sept 1991) 
FINE COAL TRANSPORTATION MODEL

\section{CONVENTIONAL COAL TRANSPORTATION COSTS}

Interior Region

(1990\$)

\begin{tabular}{|l|r|r|r||}
\hline & $\begin{array}{r}\text { Avg Haul } \\
\text { (miles) }\end{array}$ & \$/Ton & \$/Ton-mile \\
\hline Truck & 22 & 3.23 & 0.072 \\
\hline Rail & 145 & 4.88 & 0.032 \\
\hline Barge & 713 & 5.42 & 0.009 \\
\hline
\end{tabular}

Source: ElA Trends in Contract Coal Transportation, 1979-87 (Sept 1991) 


\section{FINE COAL TRANSPORTATION MODEL}

DOE/SAIC Case Study:

Jim Walters Resources/APC Gorgas Station

- Recover waste coal from 3 JWR prep plants and fire as CWS at APC Gorgas \# 8 (170 MWe).

- Gorgas \#8 Heat Input Requirement:

$1.2 \times 10^{7} \mathrm{MBtu} / \mathrm{yr}(460,000 \mathrm{tpy})$

- CWS transport via barge, pipeline, or combination. 


\section{FINE COAL TRANSPORTATION MODEL}

DOE/SAIC Case Study:

Jim Walters Resources/APC Gorgas Station

\section{Transportation Costs}

- Case 1: Pipeline to Central Site, then to Barge and Power Plant

--Total Capital Investment: $\$ 9.8 \mathrm{M}$

--Annualized Capital Cost: \$1.6M

--Annual O\&M Cost: $\quad \$ 1.0 \mathrm{M}$

--Total Annualized Cost: $\quad \$ 2.6 \mathrm{M}$

$\$ 0.209 / \mathrm{MBtu}$

- Case 2: Pipeline to Central Site, Pipeline to Power Plant

--Total Capital Investment: $\$ 7.5 \mathrm{M}$

--Annualized Capital Cost: $\$ 1.2 \mathrm{M}$

--Annual O\&M Cost: $\quad \$ 0.9 M$

--Total Annualized Cost: \$2.1M 


\section{FINE COAL TRANSPORTATION MODEL}

Spreadsheet Model Development

- Microsoft Excel as selected by UCIG membership.

- Calculates costs for each link/leg of haul route (multiple worksheets).

- Truck, rail, and barge costs determined for eight U.S. regions (EIA/FERC data).

- Equations $(\log / \log )$ developed to determine unit transport costs for each mode and region.

- Calculates required preparation and dewatering costs (capital and O\&M).

- Includes transfer costs (\$0.50 - $\$ 2.00$ per ton).

- Provides transportation costs expressed in $\$ /$ year, \$/ton, \$/ton-mile, and \$/MBtu. 


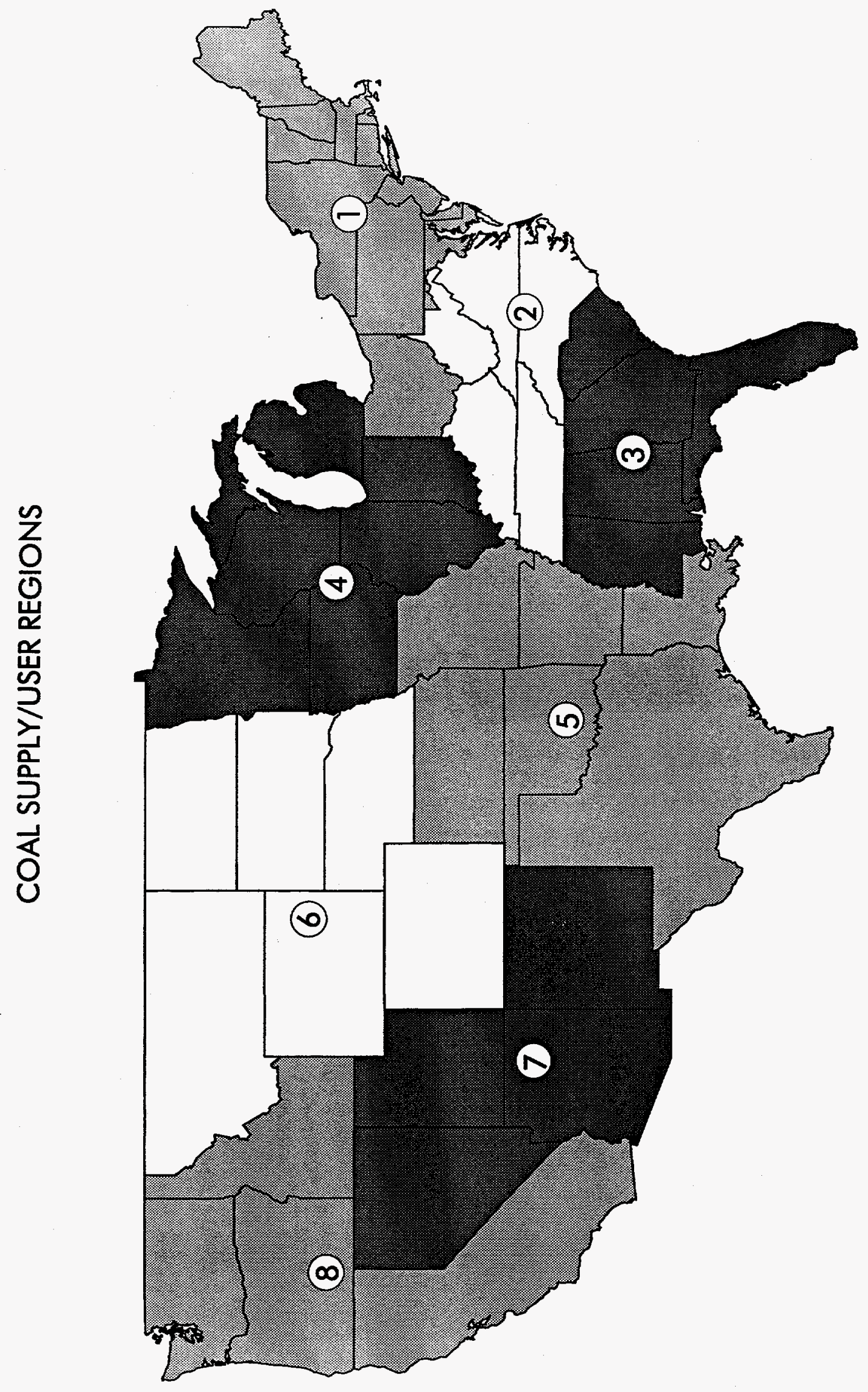




\section{Predicted Cost vs Distance \\ Region 2}

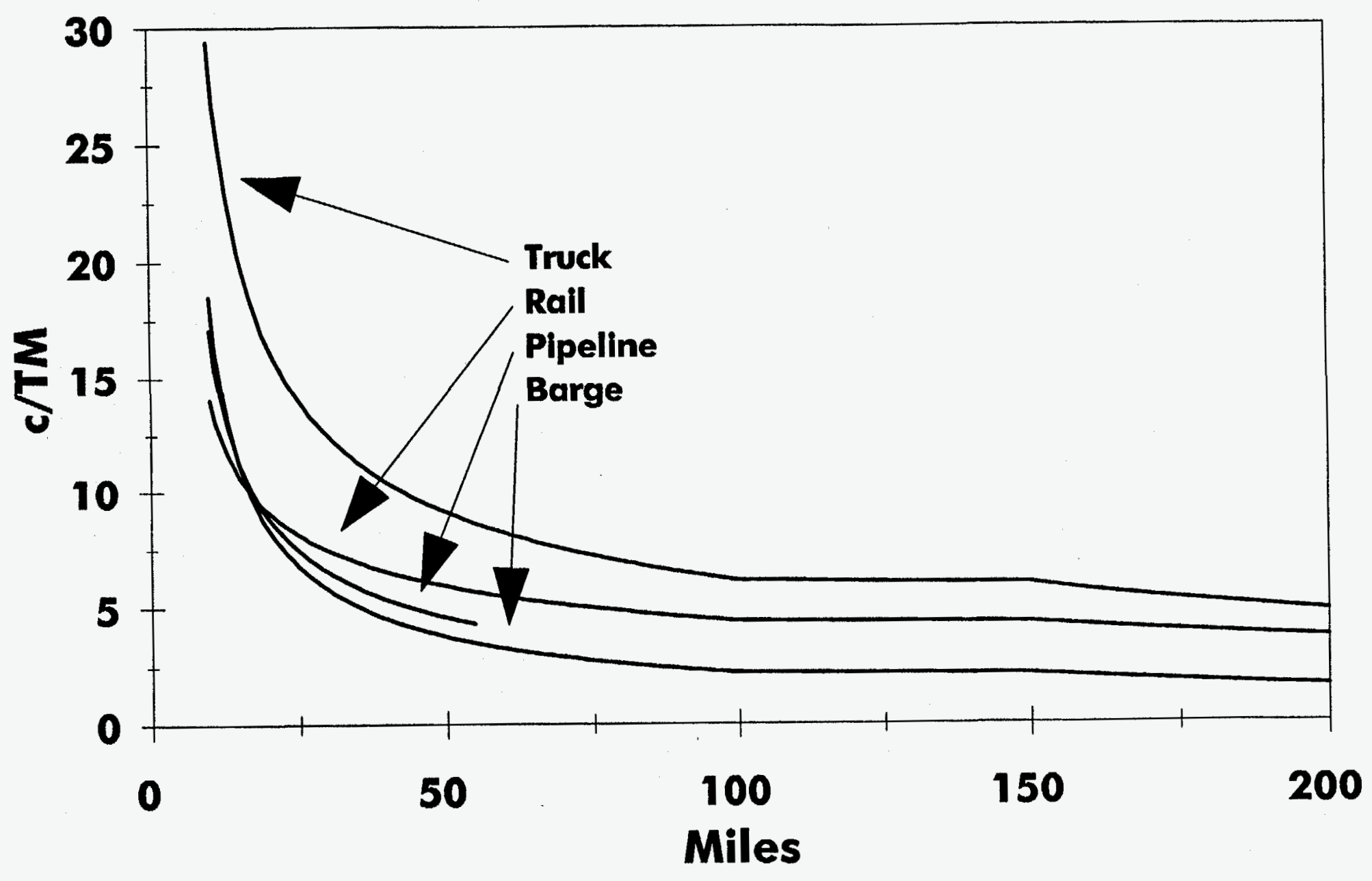




\section{FINE COAL TRANSPORTATION MODEL}

\section{EXAMPLE}

Transport Pond Fines (5M tons @ 40\% solids) from Wheatcroft, KY (Costain Pyro No. 9 Mine) to TVA Paradise Station for CWS Co-firing.

\section{Scenario 1}

- Dewater at Pond

- Transport Dewatered Fines (truck, rail, barge)

- Reslurry at Paradise

\section{Scenario 2}

- Prepare 50/50 CWS at Pond

- Transport CWS (truck, rail, barge, pipeline)

Transport Distances:

- Truck from Pond to Ohio River Dock (Caseyville, KY): $13 \mathrm{mi}$.

- Barge from Pyro Dock to Paradise Dock (Ohio \& Green rivers): $177 \mathrm{mi}$.

- Truck from Pond to Paradise: $70 \mathrm{mi}$.

- Rail or CWS Pipeline: 50 mi. 


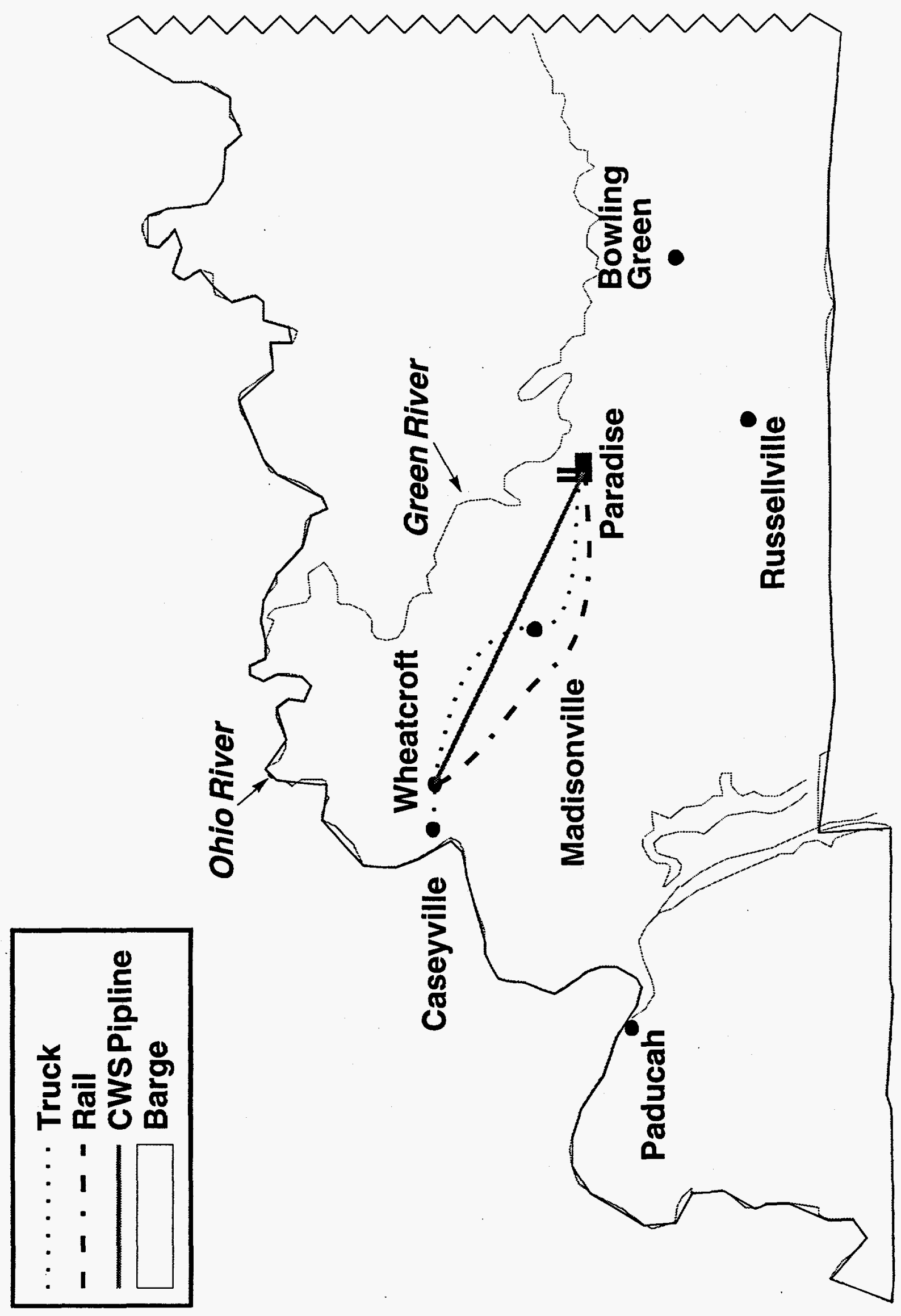




\section{FINE COAL TRANSPORTATION MODEL}

\section{PARADISE/COSTAIN EXAMPLE}

\section{Transportation Costs}

\begin{tabular}{|l|l|l|r|r||}
\hline Scenario & Material & $\begin{array}{l}\text { Transport } \\
\text { Mode }\end{array}$ & $\begin{array}{c}\text { Transport } \\
\text { \$/ton* }\end{array}$ & $\begin{array}{c}\text { Total } \\
\$ / \text { ton }^{* *}\end{array}$ \\
\hline IA & Solids & Truck/Barge & 5.17 & 14.08 \\
\hline 1B & Solids & Truck & 3.16 & 12.07 \\
\hline 1C & Solids & Rail & 2.09 & 11.00 \\
\hline & & & & \\
\hline 2A & CWS & Tanker Truck/Barge & 6.48 & 12.78 \\
\hline 2B & CWS & Tanker Truck & 5.61 & 11.91 \\
\hline 2C & CWS & Rail Tankcars & 3.40 & 9.70 \\
\hline 2D & CWS & Pipeline & 2.72 & 9.02 \\
\hline
\end{tabular}

* Transportation costs are on a wet ton basis and include all transfer costs.

** Total costs include transportation, transfer, and any required dewatering and CWS preparation facilities. 
ETCi

EXPORTech Company, Inc.

\author{
PRESENTATION TO \\ UPGRADED COAL INTEREST GROUP \\ PITTSBURGH, PA \\ SEPTEMBER 7, 1995
}

BRADLEY - ETCi

MAG-MILL

\author{
A JOINT VENTURE BETWEEN \\ EXPORTech Company, Inc. \\ Building 242, Schreiber Industrial District \\ P.O. Box 588 \\ New Kensington, PA 15068-0588 \\ (412) $337-4415$ / FAX (412) $337-4470$ \\ and \\ BRADLEY PULVERIZER COMPANY \\ 123 South Third Street \\ P.O. Box 1318 \\ Allentown, PA 18105 \\ (610) 434-5191 / FAX (610) $770-9400$
}




\section{PULVERIZER MODIFICATION FOR PYRITE SEPARATION}

AT A POWER PLANT

TEAM:

EXPORTech Company, Inc.

BRADLEY PULVERIZER COMPANY

CENTRAL ILLINOIS PUBLIC SERVICE CO.

TENNESSEE VALLEY AUTHORITY

UPGRADED COAL INTEREST GROUP

WEST PENN POWER

PHASE II GOALS:

IDENTIFY RESPONSIVE COALS

SAMPLE 3 MILLS

DEMONSTRATE MAGNET SCALABILITY

PREPARE FINAL DESIGN/ESTIMATE FOR RETROFIT 


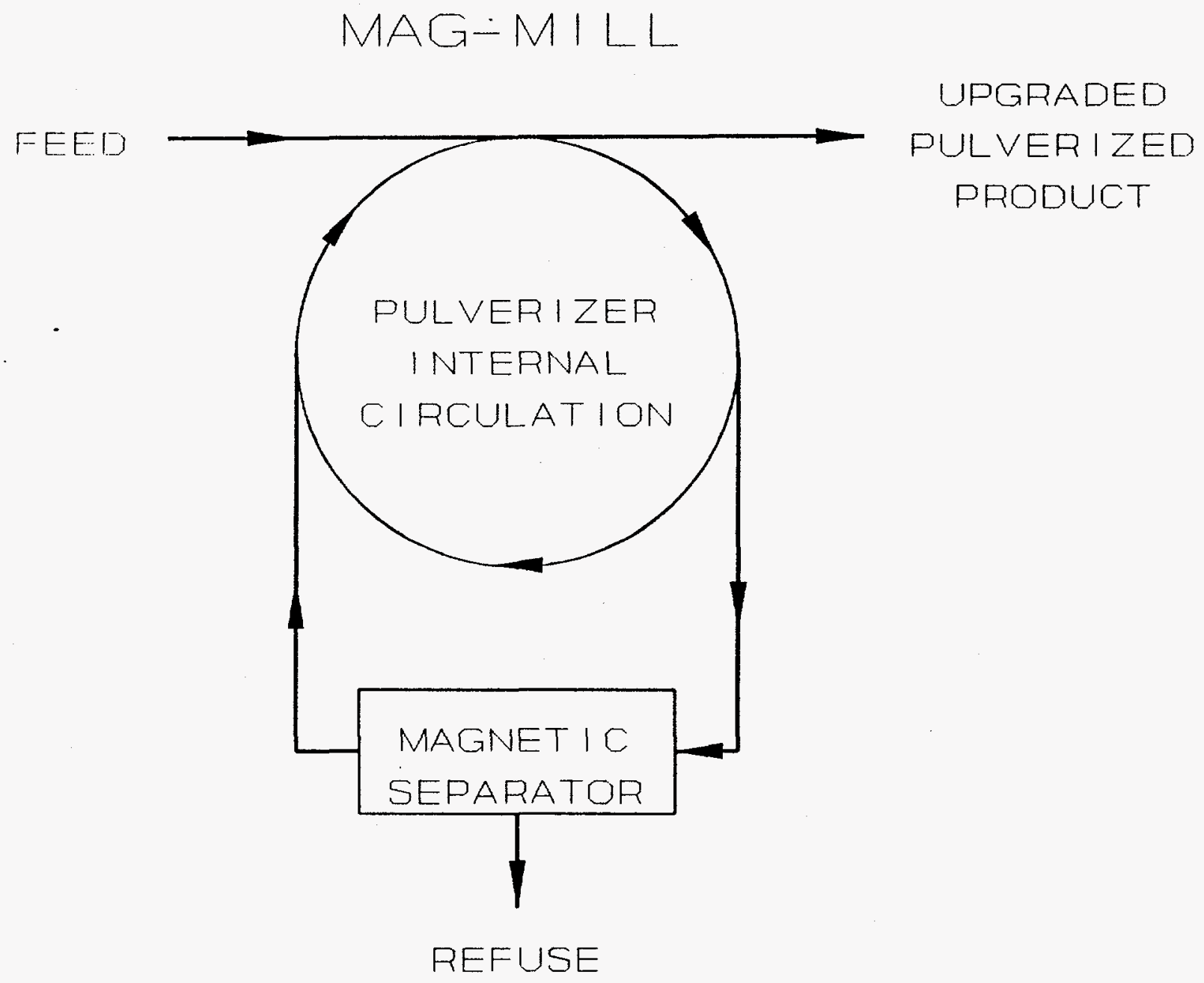




\title{
ADVANTAGES
}

\author{
BROADENS FUELS PROCUREMENT OPTIONS \\ LOWERS \\ FUELS PROCUREMENT COSTS \\ LOWERS \\ SCRUBBER COSTS \\ LOWERS \\ OPERATINGANDMAINTENANCECOSTS \\ REMOVES ABRASIVES \\ LOWERS COAL ASH \\ INCREASES PULVERIZER THROUGHPUT \\ REMOVES TRACE ELEMENTS
}




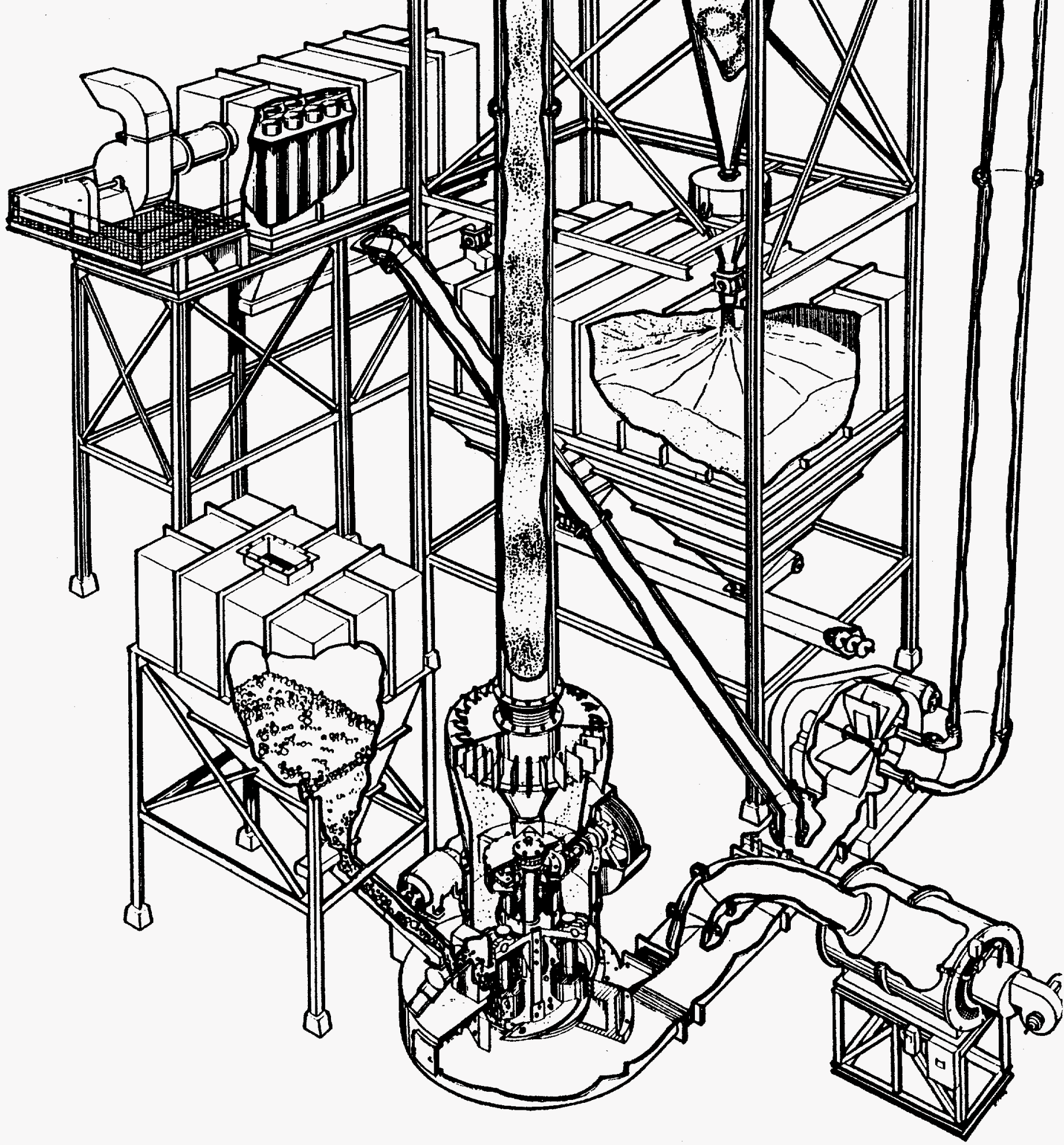




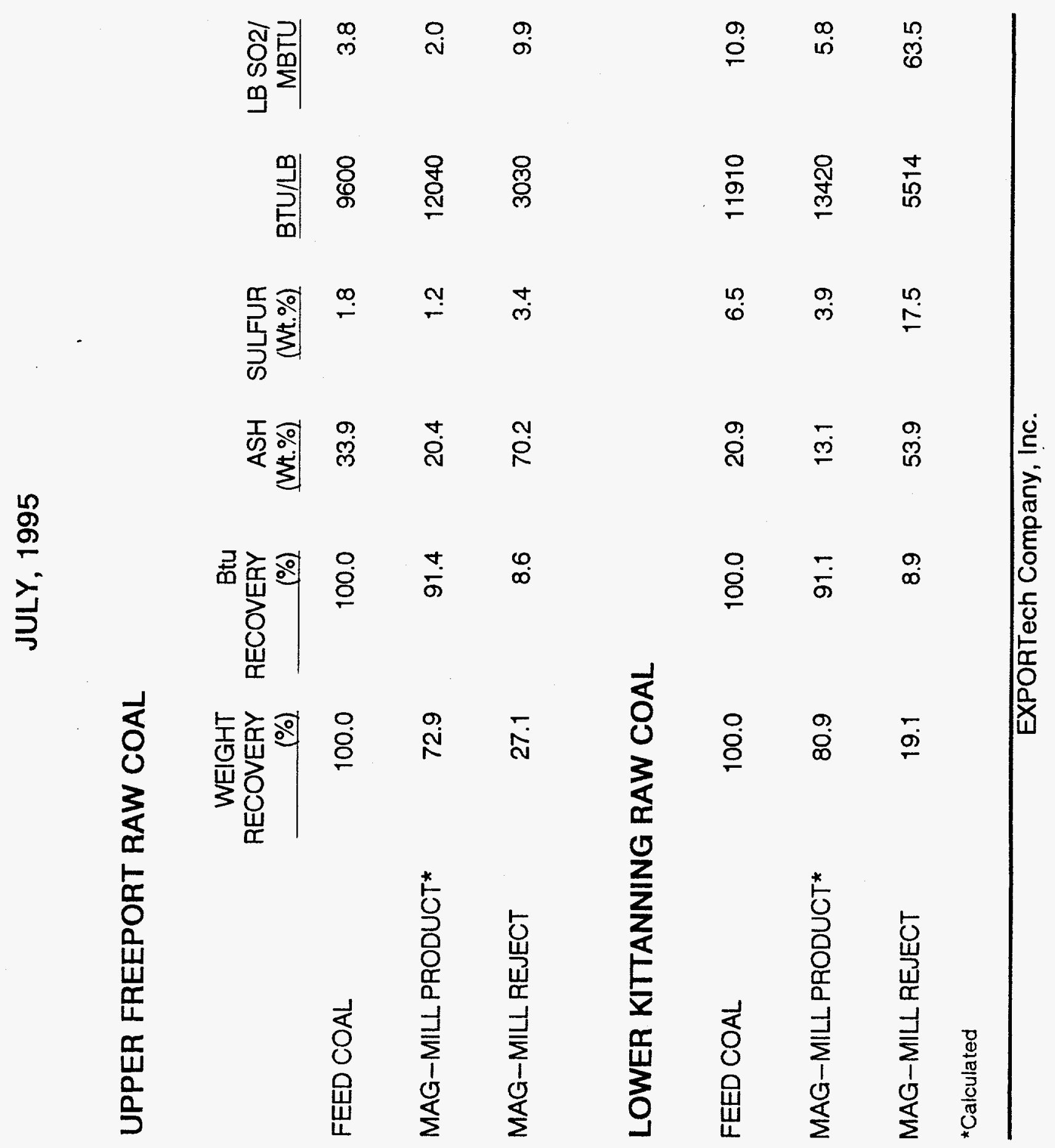




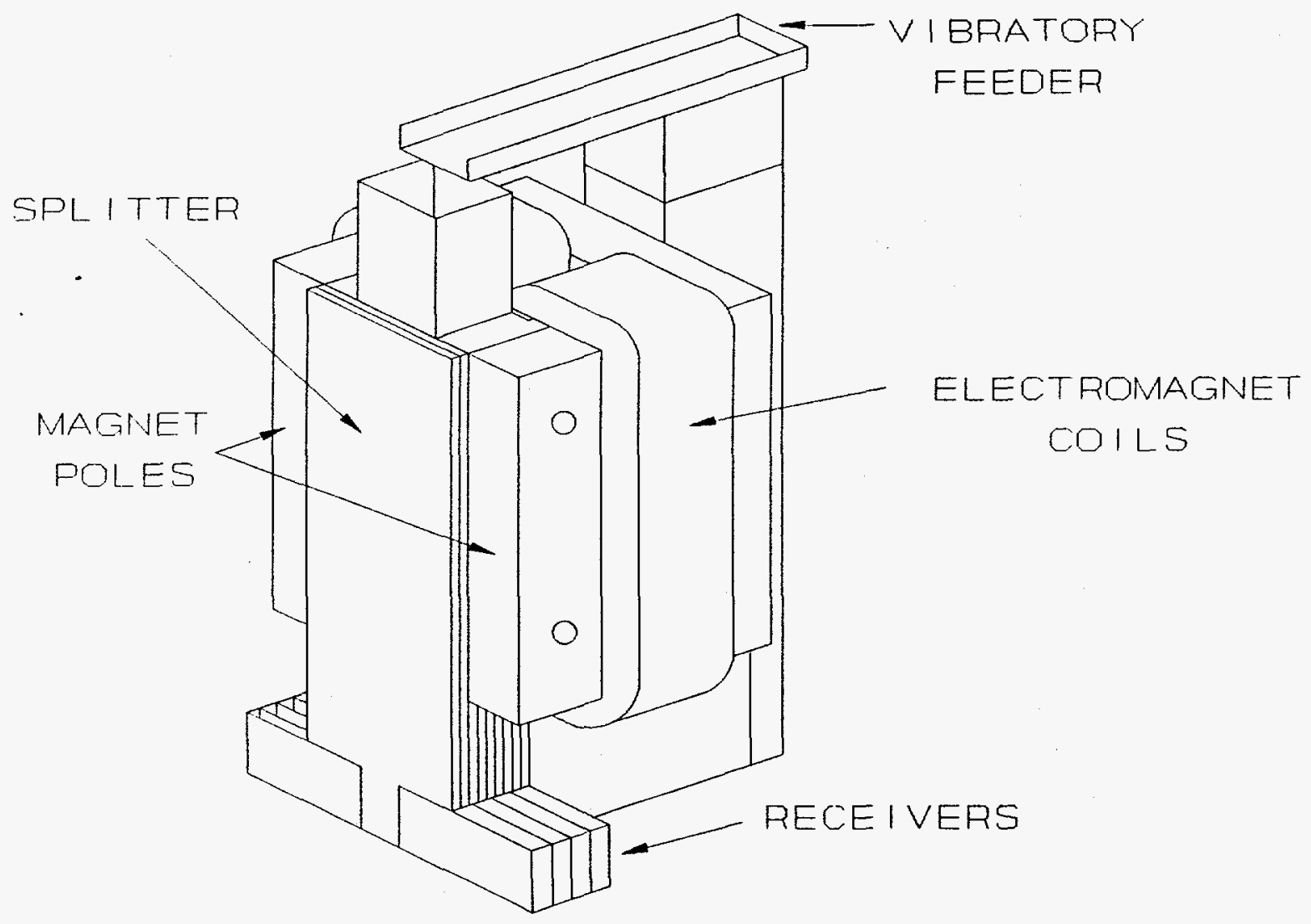

